\title{
$\mathrm{RCP}$ 시나리오 기반 농업용 저수지의 내한능력 평가
}

\section{Assessment of Anti-Drought Capacity for Agricultural Reservoirs using RCP Scenarios}

\author{
박나영** 최진용 ${ }^{* *+} \cdot$ 유승환 ${ }^{* * *}$ - 이상현* \\ Park, Na-Young · Choi, Jin-Yong · Yoo, Seung-Hwan · Lee, Sang-Hyun
}

\begin{abstract}
Agriculture is affected directly by climate conditions and changes, and it is necessary to understand the impact of climate change on agricultural reservoirs which are the main water resources for paddy fields in Korea. This study aimed to evaluate the impact of climate change on the anti-drought capacity including water supply capability (WSC) and drought response ability (DRA) of agricultural reservoirs based on RCP (Representative Concentration Pathway) 4.5 and 8.5 scenarios of CanESM2 (The Second Generation Earth System Model) provided by CCCma (Canadian Center for Climate Modeling and Analysis). The WSC and DRA were estimated using frequency analysis and runs theory. The six reservoirs (Yooshin, Nogok, Kumsung, Songgok, Gapyung, Seoma) were selected considering geographical characteristics and design criteria of reservoir capacity. In case of Seoma reservoir, more than 10 year drought return period (DRP), the variation of the WSC was estimated larger than the others. In case of Yooshin reservior (2 5 DRP) DRC was decreased in 2025s under RCP8.5. These results could be utilized for agricultural reservoirs management and future design criteria considering climate change impacts on paddy irrigation.
\end{abstract}

Keywords: Climate Change; RCP; CanESM2; Agricultural Reservoir; Runs theory

\section{I. 서 론}

농업은 다른 산업과 달리 기상과 환경 변화에 크게 좌우되는 분야로, 기후변화에 민감하다. 우리나라의 최근 10년 (2001 2010년) 평균기온은 $12.9{ }^{\circ} \mathrm{C}$ 로 과거 10년 (1971 1980년) 보 다 $0.7{ }^{\circ} \mathrm{C}$ 상승하였고, 10 년 평균 연강수량은 $1,407.6 \mathrm{~mm}$ 로 과 거에 비해 약 $11 \%$ 증가하였다. 또한, 집중호우일수 (일강수량 $80 \mathrm{~mm}$ 이상 일수)도 2.62 일로 과거 (1.68일) 보다 증가하는 것 으로 나타나 기후변화 현상이 심화되고 있음을 보여주고 있다 (KMA, 2011). 기후변화가 농업용수 수요에 미치는 주요 요인으 로는 기온 상승과 강수량 증가로 나누어 볼 수 있다. 기온 상승 은 증발산량 증가로 이어져 관개용수 증가의 원인이 된다. 강수

* 서울대학교 생태조경-지역시스템공학부 대학원

** 서울대학교 조경-지역시스템공학부 부교수, 농업생명과학연구원 겸임연구원

*** Department of Agricultural and Biological Engineering, Purdue University, Visiting scholar

$\dagger \quad$ Corresponding author Tel.: +82-2-880-4583

Fax: $+82-2-873-2087$

E-mail: iamchoi@snu.ac.kr

2013년 2월 4일 투고

2013년 4월 17일 심사완료

2013년 4월 18일 게재확정
량의 증가는 관개용수의 감소의 원인이, 계절별 강우 편차 및 강 우강도의 변화는 유효우량의 감소 또는 증가의 원인이 될 수 있 다 (Yoo et al., 2012a). 이와 같이 기후변화는 농업용수 수요에 다양하게 영향을 주므로 농업용수의 약 $60 \%$ 를 공급하는 주요 공급수리시설물인 농업용 저수지에 대한 기후변화 대응능력을 평가하는 것은 농업수자원 관리 측면에서 필요한 사항이다.

농업용 저수지는 전국에 약 18,000 여개가 축조되어 있으며, 내한 능력도 상이하다. 설계 한발기준은 현재 10년으로 되어있 지만, 실제 내한능력은 2 년부터 10년 이상 까지 존재하고 있다.

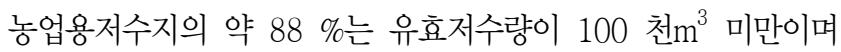
나머지 $12 \%$ 도 그 크기가 다양하고 설계년도와 지역에 따라 용 수공급능력이 상이하므로, 설계년도와 지역별로 농업용 저수지의 기후변화에 대한 내한능력 평가가 필요하다.

기후변화에 따른 농업수자원에 미치는 영향에 대한 연구를 살 펴보면, IPCC (Intergovernmental Panel on Climate Change) 4차 평가보고서에서 사용한 SRES (Special Report on Emissions Scenarios) 기반 미래 기상자료를 활용하여 Park et al. (2009) 은 저수지의 유입량과 저수량에 대한 기후변화 영향을 평가하였 고, Park et al. (2010)은 SLURP 수문모형을 이용하여 기후, 토 지이용 및 식생의 변화가 저수지의 유입량 및 저수량에 미치는 영향을 분석하였다. 이 외에도 논벼를 중심으로 소비수량, 필요 
수량, 10 년 빈도 논용수 수요량, 그리고 단위용수량에 대한 연구 가 진행된바 있다 (Hong et al., 2009; Yun et al., 2011; Lee et al., 2012; Yoo et al., 2012a). 최근에는 IPCC 5차 평가보 고서에서 사용될 RCP (Representative Concentration Pathway) 시나리오를 활용한 연구가 시작되고 있으며, Chung (2012)은 서해안 평야지대 6 개소에 대해 논벼의 소비수량을 추정하였고 $\mathrm{RCP} 4.5$ 보다 RCP8.5에서 그 증가가 클 것으로 예측하였다.

안정적이고 지속적인 농작물 생산을 위해 농업용 저수지에 대 한 용수공급능력을 평가한 연구를 살펴보면 다음과 같다. Kim et al. (1998)은 저수지의 저류량과 강수량의 확률통계적인 해석 을 통해 관개용 저수지의 용수공급능력을 정량적으로 수치화하 였고, Park et al. (1999)은 다목적댐의 유입량자료를 이용하여 용수공급능력을 평가하고자 Runs 이론 (theory of run)에 따라 빈도개념의 가뭄심도를 추정하였다. Ahn et al. (2002)은 소규모 저수지의 저류량과 용수공급능력 결정을 위해 천이확률행렬법 및 모의발생방법, 선형계획법을 적용하여 각 방법에 따른 용수공급 량을 비교·검토하였고 그 결과 모의발생방법이 합리적인 것으로 제시한 바 있다. Park et al. (2002)은 용수공급의 부족상황을 나타낼 수 있는 위험도 평가기준을 도입하여 운영 평가를 실시 하였으며, Jang et al. (2004)은 농업가뭄평가모형인 SRADEMP 을 개발하여 관개지구의 농업가뭄 분석을 수행하였다. Lee et al. (2006)은 가뭄기간에 저수지의 용수공급능력을 모니터링 할 수 있는 물공급능력지수를 개발하여 저수지의 수요량에 대한 용수 의 공급 가능 여부를 평가하였고, Ahn et al. (2009)은 용수공급 가능량을 평가하기 위해 수요량에 대한 부족량의 비율을 용수공 급율로 정의하고 소유역별로 정리하였다. Nam et al. (2012)는 농업용 저수지의 공급량과 관개지구의 수요량의 확률통계적인 해 석을 통해 저수지의 용수공급능력을 정량적으로 수치화하여 제시 하였다.

앞서 검토된 기존의 선행 연구들은 저수지의 유입량을 기준으 로 용수공급 부족을 평가하였으나 기후변화로 인한 필요수량 변 화에 따른 가뭄에 대하여는 정량적으로 평가되지 않아 미래 농 업용 저수지의 내한 능력 평가에는 한계가 있었다. 또한, 용수공 급 부족으로 생긴 가뭄은 다른 자연재해와 달리 발생시점이 명 확하지 않으며, 가뭄심도에 따라 피해 규모의 정도가 광범위하다 는 특징을 가지고 있어 저수지의 가뭄대응능력을 평가하기 위해 서는 가뭄심도 즉, 용수수요량에 대한 공급량의 부족분을 추정하 는 것이 중요하다. 따라서 얼마나 자주 용수부족이 발생하는지, 용수부족이 발생한 이후 얼마나 빨리 정상상태로 회복하는지, 그 리고 용수부족이 결과는 얼마나 심각한 것인지에 대한 검토가 이루어지는 것이 필요하다 (Park et al., 1999).
본 연구에서는 농업용 저수지의 용수공급능력과 가뭄대응능력 을 동시에 고려한 내한능력을 평가하고자 하였다. 지역과 설계빈 도 차이에 따라 대상저수지 6 개소를 선정하였으며, 새로운 시나 리오인 RCP 기반의 미래 기상자료를 산출하였다. 용수공급능력 은 연최대 필요저수량의 빈도분석으로 평가하였고, 가뭄대응능력 은 가뭄 지속기간-크기-강도를 검토할 수 있는 Runs 이론을 적 용하여 분석하였다.

\section{II. 재료 및 방법}

본 연구에서는 IPCC 5 차 보고서에서 채택한 RCP 시나리오를 바탕으로 생성된 기후변화자료를 활용하여 농업용 저수지의 내 한능력을 평가하기 위한 방법은 다음과 같다. 첫 번째로 $\mathrm{CCCma}$ (Canadian Center for Climate Modeling and Analysis)에서 제공하는 CanESM2 (The Second Generation Earth System Model)를 바탕으로 편의보정 (Bias correction)을 활용하여 기후 변화자료를 산출하였다. 두 번째로 저수지의 물수지를 수행하기 위해서 산출된 기상자료와 DIROM (Daily Irrigation Reservoir Operation Model)을 이용하였으며, 연최대 필요저수량의 빈도분 석을 통하여 용수공급능력을 산정하였다. 마지막으로 Runs 이론 을 적용하여 기준수위 (truncation level) 대비 부족분에 대한 강 도 (severity)를 빈도분석 하였고, 5 10년 재현기간에 따른 지 속기간 (duration)과 빈도 (frequency)를 도출하여 가뭄대응능력 을 분석하였다. Fig. 1은 본 논문의 연구 방법을 흐름도로 나타 낸 것이다.

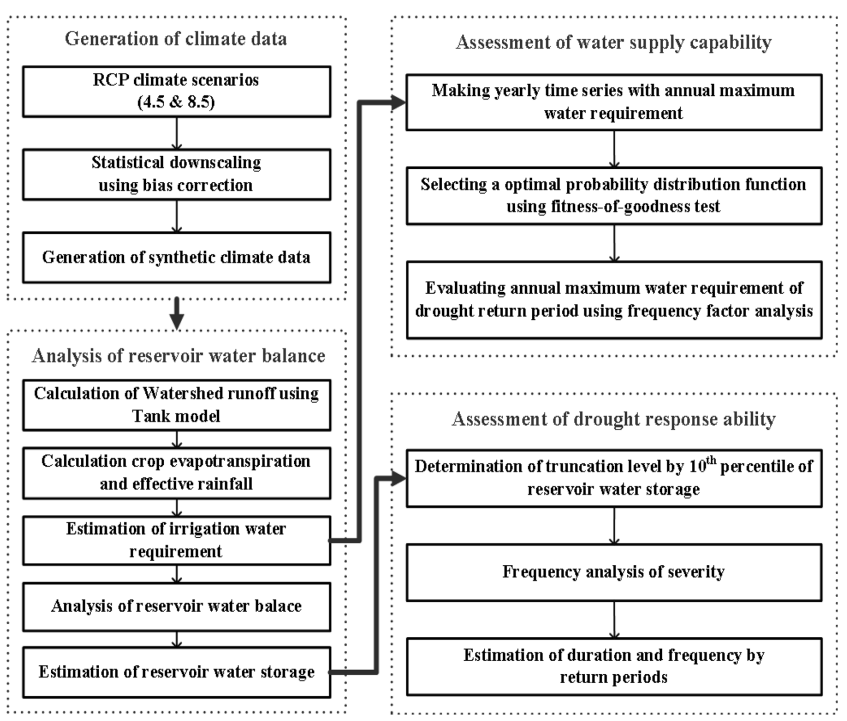

Fig. 1 A procedure diagram for assessment of anti-drought capacity affected by climate change 


\section{1. 연구대상지역}

본 연구에서는 대상저수지의 지역적 차이를 고려하기 위해 중 부지방과 남부지방으로 구분하였으며, 저수지 내용적 설계빈도를 2 5년, 5 10년, 10년 이상으로 나누어 선정하였다. Fig. 2는 우리나라의 대표 평야지대인 이천과 정읍을 중심으로 선정된 저 수지의 위치를 나타낸 것이다. 중부지방의 저수지는 이천측후소 가 지배측후소인 유신, 노곡, 금성저수지이며 남부지방의 저수지 는 정읍측후소가 지배측후소인 송곡, 가평, 서마저수지이다. Table 1 은 본 연구에서 선정한 각 저수지의 유역면적, 관개면적, 침투 량, 수로손실 및 유효저수용량 등의 기초자료로, 유역면적과 유 효저수용량이 가장 큰 저수지는 중부지방의 유신저수지이며, 관 개면적이 가장 큰 저수지는 중부지방의 금성저수지로 나타났다.

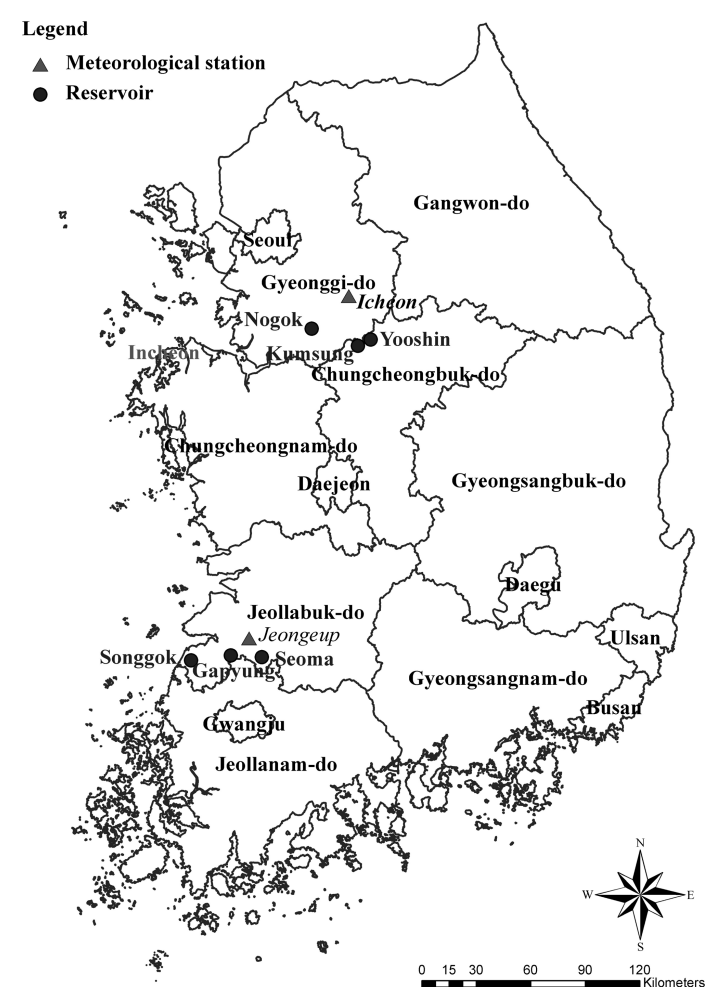

Fig. 2 Location of the reservoirs for this study

\section{2. 미래 기상자료 생성}

2007년 IPCC 4차 기후변화 평가보고서 발간 이후, 2013 2014년 발간 예정인 5차 기후변화 평가보고서를 위하여 IPCC 는 표준 온실가스 시나리오를 대표농도경로 $(\mathrm{RCP})$ 로 새롭게 선 정하였다. 종래의 순차적인 접근방법인 SRES 시나리오와 달리 $\mathrm{RCP}$ 시나리오는 기후, 대기, 탄소 순환의 예측과 온실가스 배출 및 사회 경제적 변화를 평행하게 접근함으로서 정보전달의 시간 지연 문제점을 보완할 수 있어 더 나은 기후예측을 할 수 있을 것이다 (NIMR, 2011). RCP 시나리오에는 4종이 있으며, 현재 추세로 온실가스가 배출되는 경우 $\mathrm{RCP} 8.5$, 지구가 회복력을 가 질 수 있는 최대 한계값인 RCP2.6, 그리고 온실가스 저감 정책 이 어느 정도 실현되는 경우인 RCP4.5/6.0으로 구성되어 있다. 미래 기후변화 전망자료를 제시하기 위하여 전지구 시나리오 개 발은 세계기후연구프로그램 (WCRP, World Climate Research Programmer)의 결합모델상호비교사업 (CMIP; Coupled Model Intercomparison Project)을 통해 국제적으로 수행되고 있다. 미 래 기후변화 시나리오 산출을 위한 실험은 제어실험, 과거기후 모의실험, 미래기후변화 전망 실험으로 구성되어 있다. CMIP 홈 페이지 (http://cmip-pcmdi.llnl.gov/cmip5/availability.html)에 서는 모델별, 기후시나리오별, 기상인자별 등으로 구분하여 미래 기상자료를 제공하고 있는데, Table 2는 CMIP에 참여하고 있는 모델 중 대표적인 모델을 나타낸 것이다. (Kang et al., 2012; So et al., 2012)

본 연구에서는 $\mathrm{CMIP5}$ 에서 제공하고 있는 모델 중 $\mathrm{CCCma}$ 의 CanESM2를 선정하였다. CCCma에서는 AGCM1 (The first generation atmospheric $\mathrm{GCM}$ )을 시작으로 현재 RCP 시나리오 기반 CanESM2까지 기후 모델을 발전시켰는데, 우리나라에서는 이 기관에서 제공하고 있는 CGCM2 및 CGCM3 등의 산출물을 바탕으로 수자원과 관련한 다양한 연구에 적용한 바 있다 $(\mathrm{Lim}$ et al., 2006; Choi et al., 2010; Lee et al., 2012; Yoo et al., 2012b). 또한 일사량 등의 추가적인 기상요소자료와 365일 자료를 제공하고 있어 미래 기상자료로 활용이 가능할 것으로 판 단되었다. CanESM2는 대기와 해양의 순환모델인 CanCM4 (The

Table 1 Basic data of the six agricultural reservoirs for this study (RIMS, http://rims.ekr.or.kr; Lee, 2000)

\begin{tabular}{|c|c|c|c|c|c|c|c|}
\hline Region & $\begin{array}{l}\text { Reservoir } \\
\text { name }\end{array}$ & $\begin{array}{l}\text { Meteorological } \\
\text { station }\end{array}$ & $\begin{array}{c}\text { Watershed area } \\
\text { (ha) }\end{array}$ & $\begin{array}{l}\text { Irrigated area } \\
\text { (ha) }\end{array}$ & $\begin{array}{c}\text { Percolation } \\
(\mathrm{mm} / \text { day })\end{array}$ & \begin{tabular}{|c|} 
Conveyance losses \\
$(\%)$ \\
\end{tabular} & $\begin{array}{c}\text { Available water storage capacity } \\
\qquad\left(10^{3} \mathrm{~m}^{3}\right) \\
\end{array}$ \\
\hline \multirow{3}{*}{ Central region } & Yooshin & \multirow{3}{*}{ Icheon } & 7330 & 107.4 & 4.6 & 14 & 484.5 \\
\hline & Nogok & & 200 & 40 & 5.5 & 14 & 167 \\
\hline & Kumsung & & 285 & 115.3 & 5 & 14 & 522 \\
\hline \multirow{3}{*}{ Southern region } & Songgok & \multirow{3}{*}{ Jeongeup } & 350 & 125 & 3 & 15 & 359 \\
\hline & Gapyung & & 212 & 77 & 3 & 15 & 306 \\
\hline & Seoma & & 255.0 & 69.4 & 5.1 & 13 & 416 \\
\hline
\end{tabular}


Table 2 Information of 18 global coupled climate models (XU et al., 2012)

\begin{tabular}{|c|c|c|}
\hline Model name & Modeling center (or group) & Resolution \\
\hline Beijing Climate Center Climate System Model version 1 (BCC-CSM1-1) & BCC, China & $128 \times 64$ \\
\hline Canadian Earth System Model version 2 (CanESM2) & Canadian Centre for Climate Modelling and Analysis, Canada & $128 \times 64$ \\
\hline The Community Climate System Model version 4 (CCSM4) & The National Center for Atmospheric Research, USA & $288 \times 192$ \\
\hline $\begin{array}{l}\text { Centre National de Recherches Météorologiques Climate Model version } 5 \\
\text { (CNRM-CM5) }\end{array}$ & CNRM, France & $256 \times 128$ \\
\hline $\begin{array}{l}\text { Commonwealth Scientific and Industrial Research Organization Mark } \\
\text { Climate Model version 3.6 (CSIRO-Mk3-6-0) }\end{array}$ & CSIRO, Australia & $192 \times 96$ \\
\hline $\begin{array}{l}\text { Flexible Global Ocean-Atmosphere-Land System Model- spectral version } 2 \\
\text { (FGOALS-s2) }\end{array}$ & Institute of Atmospheric Physics, China & $128 \times 108$ \\
\hline $\begin{array}{l}\text { Geophysical Fluid Dynamics Laboratory Climate Model Version } 3 \\
\text { (GFDL-CM3) }\end{array}$ & GFDL, USA & $144 \times 90$ \\
\hline $\begin{array}{l}\text { Goddard Institute for Space Studies Model E version } 2 \text { with Russell ocean } \\
\text { model (GISS-E2-R) }\end{array}$ & GISS, USA & $144 \times 90$ \\
\hline Institute of Numerical Mathematics Climate Model version 4 (INMCM4) & INM, Russia & $180 \times 120$ \\
\hline $\begin{array}{l}\text { Institute Pierre Simon Laplace Climate Model 5A-Low Resolution } \\
\text { (IPSL-CM5A-LR) }\end{array}$ & IPSL, France & $96 \times 96$ \\
\hline $\begin{array}{l}\text { Institut Pierre Simon Laplace Climate Model 5A-Medium Resolution } \\
\text { (IPSL-CM5A-MR) }\end{array}$ & IPSL, France & $144 \times 143$ \\
\hline $\begin{array}{l}\text { Model for Interdisciplinary Research on Climate-Earth System, version } 5 \\
\text { (MROC5) }\end{array}$ & $\begin{array}{l}\text { Atmosphere and Ocean Research Institute, National Institute for } \\
\text { Environmental Studies, Japan Agency for Marine-Earth Science and } \\
\text { Technology, Kanagawa, Japan }\end{array}$ & $256 \times 128$ \\
\hline $\begin{array}{l}\text { Model for Interdisciplinary Research on Climate-Earth System } \\
\text { (MROC-ESM) }\end{array}$ & JAMSTEC, AORI, NIES, Japan & $128 \times 64$ \\
\hline $\begin{array}{l}\text { Atmospheric Chemistry Coupled Version of Model for Interdisciplinary } \\
\text { Research on Climate-Earth System (MROCESM-CHEM) }\end{array}$ & JAMSTEC, AORI, NES, Japan & $128 \times 64$ \\
\hline Max-Planck Institute Earth System Model-Low Resolution (MPI-ESM-LR) & MPI, Germany & $192 \times 96$ \\
\hline $\begin{array}{l}\text { Meteorological Research Institute Coupled General Circulation Model } \\
\text { version } 3 \text { (MRI-CGCM3) }\end{array}$ & MRI, Japan & $320 \times 160$ \\
\hline $\begin{array}{l}\text { The Norwegian Earth System Model version } 1 \text { with Intermediate Resolution } \\
\text { (NorESM1-M) }\end{array}$ & Norwegian Climate Centre, Norway & $144 \times 96$ \\
\hline $\begin{array}{l}\text { The version of NorESM1-M with prognostic biogeochemical cycling } \\
\text { (NorESM1-ME) }\end{array}$ & Norwegian Climate Centre, Norway & $144 \times 96$ \\
\hline
\end{tabular}

Fourth Generation Atmospheric General Circulation Model) 와 육상과 대기 사이의 탄소 순환을 모의하는 CTEM (Canadian Terrestrial Ecosystem Model)이 결합된 전지구순환모델 (GCM) 로, 토지이용변화를 포함하여 육상의 주요 생태계 과정을 모의하 기 때문에 향상된 미래 기상자료를 기대할 수 있다 (Chylek et al., 2011). 현재 CanESM2의 자료는 RCP2.6/4.5/8.5에 대해서 제공되고 있으며, RCP2.6 시나리오의 경우 현실에서는 실현 불 가능한 극한 시나리오이기 때문에 (KMA, 2012), 본 연구에서는 제외하고 RCP4.5와 8.5를 활용하였다.

그러나 $\mathrm{GCM}$ 의 미래 기상자료를 직접 이용한다면 상대적으로 유역 크기가 작은 농업용저수지에 적용하기에는 일부 한계가 있 기 때문에 상세화가 필요하다. 따라서 편의보정 기법을 이용하여 일별 최고, 최저, 평균 기온 및 강수량, 습도, 풍속, 일조시간 등 미래 기후변화 자료를 생성하였다. 편의보정은 현재 기후의 공
간패턴이 미래에는 변화가 없다고 가정하고, $\mathrm{GCM}$ 에서 제공하는 각 기상인자별 Historical (기준기간, 1976 2005년) 자료와 동 기간에 관측된 자료와의 평균과 표준편차의 차이를 이용하여 미 래자료를 구축하는 방법이다 (Ho et al., 2012).

본 연구에서는 중부지방의 이천측후소와 남부지방의 정읍측후 소에 대해서 CanESM2를 바탕으로 미래 90년 기간을 2011 2040년 (2025s), 2041 2070년 (2055s), 2071 2100년 (2085s) 으로 구분하여 미래 기상자료를 생성하였으며, 현재를 나타내는 1990s (기준기간)는 1976 2005년을 기준으로 하였다.

\section{3. 물수지분석 모델}

이천 측후소 및 정읍 측후소의 기준기간과 미래 기상 시나리오 를 바탕으로 저수지 물수지 분석을 통한 일별 저수량 모의를 실 
시하였다. 저수지 물수지 분석모형은 DIROM으로, 유출량은 3단 Tank 모형을 적용하여 일별로 산정되며 논 관개수량은 PenmanMonteith식에 의한 증발산량과 작물계수, 최대·최소담수심, 침 투량, 수로손실 등을 고려하여 산정된다. 저수지에서의 물수지를 식으로 나타내면 다음과 같다 (Kim and Park, 1988).

$$
S_{t}=S_{t-1}+I_{t}+P_{t}-\left(R_{t}+O_{t}+E_{t}\right)
$$

여기서, $S$ 는 저수량 (storage), $I$ 는 유입량 (inflow), $P$ 는 수면 강수량 (precipitation), $R$ 는 방류량 (release), $O$ 는 여수로월류 량 (overflow), $E$ 는 수면증발량 (evaporation) 및 $t$ 는 일 (day) 이다.

\section{4. 농업용 저수지의 용수공급능력}

농업용 저수지에서 용수공급에 대한 능력을 검토하는 방법으 로 저수지의 연최대 필요저수량을 유효저수량과 비교하여 분석 하고자 하였다. 연최대 필요저수량은 농업용수를 공급하면서 저 수지가 필요로 하는 저수량 중 연최대값을 의미하며, 연최대 필 요저수량이 유효저수량보다 많은 양을 필요로 할 경우 용수 공
급에 있어서 어려움이 발생할 수 있다. 따라서 저수지 물수지 분 석의 결과로 산출된 일별 저수량 결과로부터 연최대 필요저수량 을 산정하고 빈도분석을 실시한 후, 미래 시기의 설계빈도 변화 를 이용하여 농업용 저수지의 용수공급능력을 검토하였다.

일반적으로 빈도분석은 시계열 작성, 확률분포형 매개변수 추 정, 적합도 검정을 통한 최적확률분포형 선정, 빈도치 산정 순으 로 이루어진다. 먼저, 물수지 분석으로 모의된 연최대필요수량을 바탕으로 시계열을 작성한 후, Gamma, GEV, Gumbel, Lognormal, Weibull 등의 확률분포형에 대한 확률가중모멘트법 등 을 통한 매개변수를 추정하였다. Chi-Squared, KolmogorovSmirnov (K-S) 검정, Anderson Darling 등을 통한 최적확률분 포형을 선정한 후, 빈도계수법을 통하여 저수지의 설계빈도를 산 정하였다.

\section{5. 농업용 저수지의 가뭄대응능력}

농업용 저수지의 가뭄대응능력에 대한 평가는 일반적으로 용 수공급의 부족상황을 나타낼 수 있는 몇몇 평가지수들로서 가능 해지는데, Runs 이론은 이 상황의 특성을 세 가지의 특성치로 구분하여 분석하는 방법이다. Runs 이론에서 가뭄의 세 가지 특

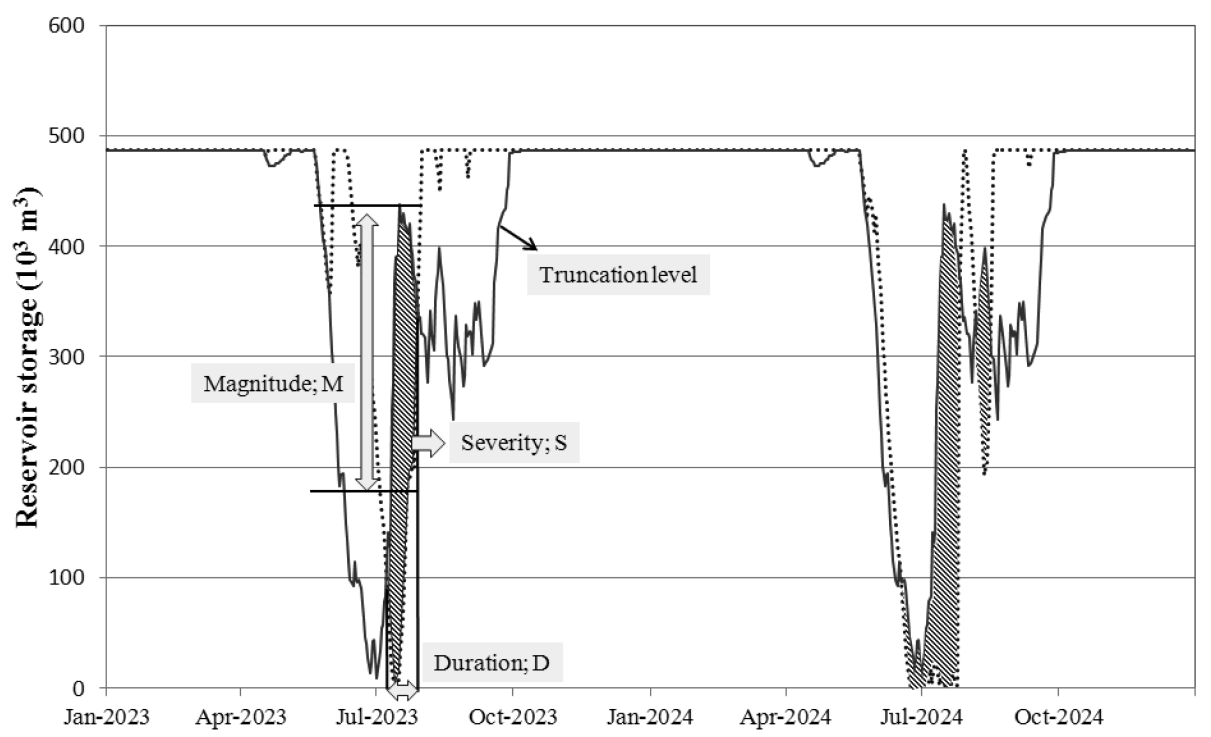

Fig. 3 Fundamental parameters of the drought events (Yooshin reservoir, RCP4.5)

$D($ day $)=$ end day of $($ reservoir storage $<$ truncation level $)-$ start day of (reservoir storage $<$ truncation level $)$

$$
\begin{gathered}
S\left(10^{3} \mathrm{~m}^{3} \times \text { day }\right)=\sum_{i=\text { start }}^{\text {end }} S R S_{i} \\
M(\%)=S / D
\end{gathered}
$$


성치는 기준수위에 대한 음의 부분 즉, 부족분에 대한 지속기간 (duration; $D$ ), 크기 (magnitude; $M$ ), 강도 (severity; $S$ )로 분 류할 수 있다. 가뭄분석에 있어서 용수수요량에 대한 공급량의 부족분을 추정하는 것이 중요하며, Runs 이론은 이 상황을 객관 적으로 평가할 수 있는 분석 방법이라 사료된다. 따라서 본 연구 에서는 Runs 이론을 저수지의 저수량에 도입하여 저수지의 가뭄 대응능력을 평가하고자 하였다. Runs 이론의 기준수위를 기준기 간의 일별 저수량에 대하여 하위 $10 \%$ 값으로 정의하였는데, 일 반적으로 농업용 저수지는 이수안전도 $90 \%$ 를 기준으로 설계 (MAF, 2002) 되어 있기 때문에 이를 반영하고자 하였다. 저수 량에 의한 용수공급능력의 부족의 시작은 미래시기의 저수량이 기준수위 이하로 내려가는 시점으로 하였고, 가뭄의 종료는 강우 에 의해 충분한 유입량으로 저수량이 회복 될 때로 정의하였다. 다음은 정의한 가뭄 특성치를 나타낸 것이다.

여기서, truncation level은 Runs 이론의 기준수위로써 일별 저 수량의 하위 $10 \%$ 값을 의미하며, SRS (Shortage of Reservoir Storage)는 이 기준수위에서 현재의 저수량을 뺀 값이다. 위 식 의 $D, S, M$ 을 표현하면 Fig. 3 과 같다.

\section{III. 결과 및 고찰}

\section{1. 미래 기상자료 산출}

$\mathrm{CCCma}$ 에서 제공하는 CanESM2를 편의보정으로 상세화하여 중부 지방과 남부 지방의 대표 측후소별로 모의하였다. Fig. 4 와 Table 3 은 시기별 평균 연강수량과 계절별 평균 온도를 나타 낸 것이다.

연강수량 결과를 살펴보면, 기준기간의 경우 중부지방이 1,329 $\mathrm{mm}$, 남부지방이 $1,325 \mathrm{~mm}$ 로 중부지방이 남부지방보다 많은 연 강수량을 나타내었다. RCP4.5 시나리오의 경우 중부지방에서는 기준기간과 비교하여 $2025 \mathrm{~s}$ 에는 $10.2 \%, 2055 \mathrm{~s}$ 에는 $21.0 \%$ 로 증가하였고, $2085 \mathrm{~s}$ 에는 $1990 \mathrm{~s}$ 와 비교하여 $17.2 \%$ 로 증가하였 으나 2055s보다는 감소하는 것으로 나타났다. 남부지방은 기준 기간과 비교하여, $2025 \mathrm{~s}$ 에는 $21.5 \%, 2055 \mathrm{~s}$ 에는 $27.5 \%, 2085 \mathrm{~s}$ 에는 $28.6 \%$ 로 강수량 증가를 보였으며, 중부지방보다 증가 폭 이 더 클 것으로 예상되었다. RCP8.5 시나리오의 경우 중부지방 에서는 $1990 \mathrm{~s}$ 과 비교하여 연강수량이 $2025 \mathrm{~s}$ 에는 $9.9 \%, 2055 \mathrm{~s}$ 에는 $17.4 \%, 2085 \mathrm{~s}$ 에는 $32 \%$ 증가하는 것으로 나타났고, 남부 지방에서는 $2025 \mathrm{~s}$ 에서 $13.3 \%, 2055 \mathrm{~s}$ 에서 $32 \%, 2085 \mathrm{~s}$ 에서 $50.8 \%$ 증가하는 것으로 나타났다. 즉, 연강수량의 증가 경향은 중부지방보다는 남부지방에서, RCP4.5 시나리오보다는 RCP8.5 시나리오에서 크게 나타났다.

계절별 평균 온도 산정 결과를 기준기간과 비교하여 살펴보면,

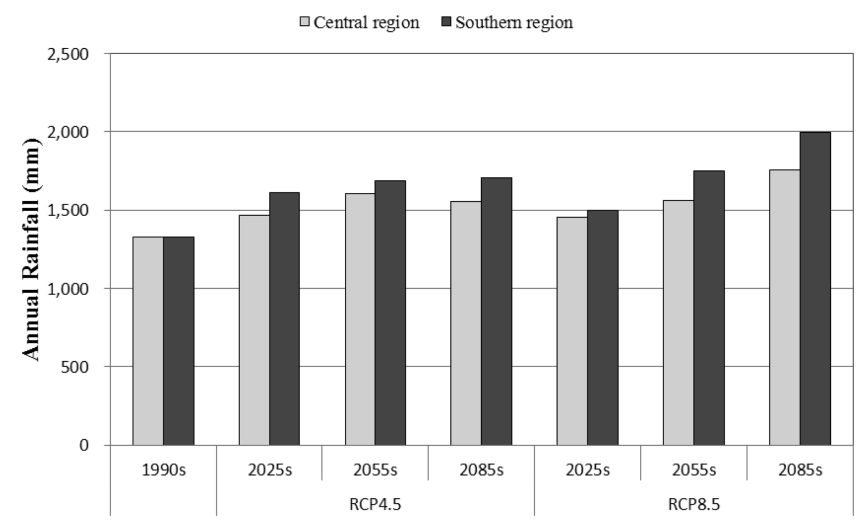

Fig. 4 Annual rainfall in two regions for RCP4.5, RCP8.5 during 1990s, 2025s, 2055s and 2085s

Table 3 Seasonal mean temperature

\begin{tabular}{|c|c|c|c|c|c|c|c|c|}
\hline \multirow{3}{*}{ Region } & \multirow{3}{*}{ Season } & \multirow{2}{*}{ 1990s } & \multicolumn{3}{|c|}{ RCP4.5 } & \multicolumn{3}{|c|}{ RCP8.5 } \\
\hline & & & $2025 \mathrm{~s}$ & $2055 \mathrm{~s}$ & $2085 \mathrm{~s}$ & $2025 \mathrm{~s}$ & $2055 \mathrm{~s}$ & $2085 \mathrm{~s}$ \\
\hline & & $\left({ }^{\circ} \mathrm{C}\right)$ & \multicolumn{3}{|c|}{$\left({ }^{\circ} \mathrm{C}\right)$} & \multicolumn{3}{|c|}{$\left({ }^{\circ} \mathrm{C}\right)$} \\
\hline \multirow{4}{*}{$\begin{array}{c}\text { Central } \\
\text { region }\end{array}$} & $\mid \overline{D J G^{1)}}$ & $\overline{-2.1}$ & 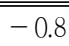 & 0.0 & 0.2 & " -0.6 & 0.6 & $\overline{\overline{1.9}}$ \\
\hline & $\mathrm{MAM}^{22}$ & 11.2 & 12.2 & 13.0 & 13.5 & 12.4 & 13.6 & 15.3 \\
\hline & $\mathrm{JJA}^{3)}$ & 23.6 & 25.1 & 26.5 & 27.2 & 25.7 & 27.5 & 29.9 \\
\hline & $\mathrm{SON}^{4)}$ & 12.5 & 13.5 & 14.8 & 15.3 & 13.8 & 15.6 & 17.3 \\
\hline \multirow{4}{*}{$\begin{array}{c}\text { Southern } \\
\text { region }\end{array}$} & DJG & 0.8 & 3.0 & 5.0 & 5.6 & 3.4 & 5.6 & 8.2 \\
\hline & MAM & 11.8 & 14.1 & 15.6 & 16.5 & 14.1 & 16.5 & 19.0 \\
\hline & JJA & 24.3 & 26.4 & 28.2 & 29.0 & 26.7 & 29.7 & 32.6 \\
\hline & SON & 14.5 & 16.4 & 18.6 & 19.5 & 16.9 & 20.0 & 23.1 \\
\hline
\end{tabular}

1) DJG: December, January and February

2) MAM: March, April and May

3) JJA: June, July and August

4) SON: September, October and November

중부지방에서는 RCP4.5 시나리오의 $2025 \mathrm{~s}$ 경우 가을 (SON; September, October and November)에 $1.0{ }^{\circ} \mathrm{C}$ 로 가장 작은 상 승 폭을 나타냈고, 남부지방에서 RCP8.5 시나리오의 2085s 경 우 가을 $(\mathrm{SON})$ 에 $8.6{ }^{\circ} \mathrm{C}$ 로 가장 큰 상승 폭을 나타냈다. 특히 논 벼의 경우 여름 (JJA; June, July and August) 시기에 온도 변화 가 수확량에 큰 영향을 미치기 때문에 그 변화를 예측하는 것이 중요한데, 중부지방에서 $\mathrm{RCP} 4.5$ 시나리오는 $1.5 \sim 3.6{ }^{\circ} \mathrm{C}, \mathrm{RCP}$ 8.5는 $2.1 \sim 6.4{ }^{\circ} \mathrm{C}$ 증가하였으며, 남부지방에서는 $\mathrm{RCP} 4.5$ 시나 리오에서 $2.1 \sim 4.7{ }^{\circ} \mathrm{C}, \mathrm{RCP} 8.5$ 에서는 $2.4 \sim 8.3{ }^{\circ} \mathrm{C}$ 증가하는 것으로 나타나 중부지방보다는 남부지방에서 증가가 클 것으로 예상된다.

\section{2. 유출량 및 논벼 작물증발산량 산정}

미래 기상자료를 바탕으로 Tank 모형을 이용하여 유역의 유출 
량을 산정하였고, 그 결과는 Fig. 5 와 같다. 중부지방에서는 RCP 4.5 시나리오의 경우 기준기간과 비교하였을 때 $2025 \mathrm{~s}$ 에는 99.1 $\mathrm{mm}$ (13.1\%), 2055s에는 $194.3 \mathrm{~mm}$ (25.7\%), 2085s에는 154.8 $\mathrm{mm}$ (20.5\%)증가할 것으로 분석되었으며, 반면에 $2085 \mathrm{~s}$ 에서는 $2055 \mathrm{~s}$ 를 기준으로 감소하는 경향을 나타내었다. RCP8.5 시나리 오의 경우는 기준기간과 비교하여 2025s에는 $95.9 \mathrm{~mm}$ (12.7\%), 2055s에는 $161.6 \mathrm{~mm}$ (21.4\%), 2085s에는 $295 \mathrm{~mm}$ (39.1\%) 로 기후변화에 따라 지속적인 증가가 예상된다. 이와 같은 경향 성은 설계빈도보다 지역별로 유사하게 나타났는데, 유출량의 경 우 강우 증감에 큰 영향을 받기 때문에 미래의 강우량 증가 패턴 과 흡사한 것으로 판단된다.

남부지방에서는 RCP4.5 시나리오의 경우 기준기간과 비교하 였을 때 $2025 \mathrm{~s}$ 에는 $208.7 \mathrm{~mm}$ (28.3\%), 2055s에는 $259.4 \mathrm{~mm}$ (35.2\%), 2085s에는 $266.8 \mathrm{~mm}(36.2 \%)$ 증가할 것으로 산 정되었으며, RCP8.5 시나리오의 경우는 2025s에는 $130.6 \mathrm{~mm}$ (17.7\%), 2055s에는 $305.1 \mathrm{~mm}$ (41.4\%), 2085s에는 490.4

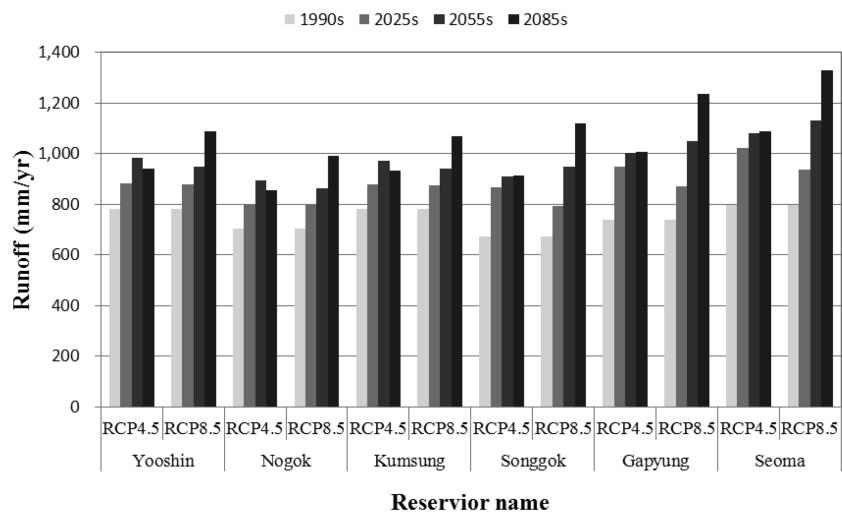

Fig. 5 Annual runoff in six reservoirs for RCP4.5, RCP8.5 during 1990s, 2025s, 2055s and 2085s

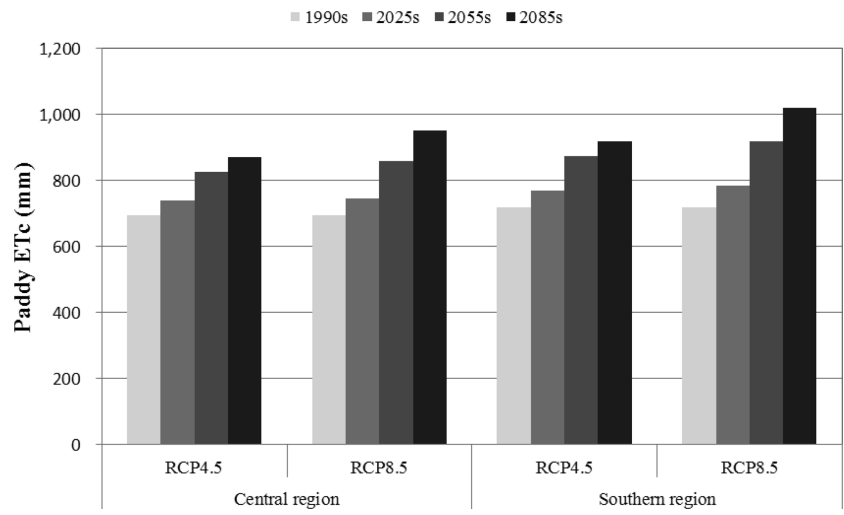

Fig. 6 The average of total paddy rice evapotranspiration $(\mathrm{ETC})$ in six reservoirs for RCP4.5, RCP8.5 during $1990 \mathrm{~s}, 2025 \mathrm{~s}, 2055 \mathrm{~s}$ and $2085 \mathrm{~s}$ $\mathrm{mm}(66.5 \%)$ 로 두 시나리오 모두 미래의 기후변화에 따라 지속 적으로 증가할 것으로 추정되며 특히 남부지방에서 그 증가율이 클 것으로 예상되었다.

Fig. 6은 Penman-Monteith 공식을 이용하여 기준작물증발산 량을 산정한 후, 논벼의 작물계수를 활용하여 미래의 논벼증발 산량의 변화를 나타낸 것이다. 중부지방에서 기준기간의 증발산 량은 $693.5 \mathrm{~mm}$ 이었으며, RCP4.5 시나리오의 경우 $2025 \mathrm{~s}$ 에는 $738.4 \mathrm{~mm}, 2055 \mathrm{~s}$ 에는 $826.1 \mathrm{~mm}, 2085 \mathrm{~s}$ 에는 $869.8 \mathrm{~mm}$ 로 추정되었다. RCP8.5시나리오의 경우는 $2025 \mathrm{~s}$ 에서 $746.8 \mathrm{~mm}$, $2055 \mathrm{~s}$ 에서 $857.9 \mathrm{~mm}$ 그리고 2085s에서 $949.8 \mathrm{~mm}$ 로 지속적 인 증가를 나타냈다. 남부지방에서는 기준기간에 $719.3 \mathrm{~mm}$ 이었 으며, RCP4.5 시나리오에서는 미래시기 (2025s, 2055s, 2085s) 에 따라 $769.1 \mathrm{~mm}, 872.3 \mathrm{~mm}, 919.7 \mathrm{~mm}$ 로 예상되었으며, $\mathrm{RCP} 8.5$ 시나리오에서는 $784.3 \mathrm{~mm}, 916.9 \mathrm{~mm}, 1020.5 \mathrm{~mm}$ 로 나타났다. 논벼 증발산량 증가율을 지역별로 살펴보면, 중부지방 보다 남부지방에서 클 것으로 예상되었는데, 이는 온도 증가가 남부지방에서, RCP8.5 시나리오에서 크게 나타났기 때문으로 판 단된다.

\section{3. 농업용 저수지 물수지 모의}

$\mathrm{DIROM}$ 모형에 의한 6 개 대상저수지의 30 년 평균 물수지 모 의 결과는 Table 4 와 같다. 저수지 유입량은 저수지 유역에서의 유출량을 의미하며, 방류량은 일별 필요수량을 만족할 수 있도록 관개를 위해 사용한 수량이고, 월류량은 저수지 유입량으로부터 수위가 만수위 시 자연 월류하는 양으로 산정하였다.

저수지의 유입량의 경우 기준기간과 비교하여 가장 작게 증가 한 경우는 중부지방의 10 년 빈도 이상 저수지인 금성 저수지로 $\mathrm{RCP} 8.5$ 시나리오의 $2025 \mathrm{~s}$ 에서 $8.5 \%$ 증가했으며, 가장 크게 증 가한 경우는 남부지방의 5 10년 빈도 저수지인 가평 저수지로 $\mathrm{RCP8.5}$ 시나리오의 2085s에서 $67.1 \%$ 증가를 보였다. 또한, 모 든 저수지에 대해서 RCP8.5 시나리오의 2025s에서는 다른 시 기와 비교하여 작은 증가 (평균 $14.7 \%$ )를 나타내었고 RCP8.5 시나리오의 $2085 \mathrm{~s}$ 에서는 큰 증가 (평균 $52.2 \%$ )를 보였는데, 이 는 저수지의 유입량의 경우 강수량과 밀접한 관계가 있기 때문 에 미래시기의 강우 증가 패턴과 유사함을 알 수 있다.

저수지의 방류량의 경우 기준기간 대비 가장 작게 증가한 경 우는 남부지방의 가평저수지로 RCP4.5 시나리오의 $2025 \mathrm{~s}$ 에서 $-4.5 \%$ 로 감소하는 것으로 나타났고, 가장 크게 증가한 경우는 중부지방의 2 5년 빈도 저수지인 유신 저수지로 $7.1 \%$ 증가를 보였다. 또한, 중부지방 저수지의 경우 기준기간과 비교하였을 때 $\mathrm{RCP} 4.5$ 시나리오의 $2055 \mathrm{~s}$ 에서 가장 작은 증가 (평균 $0.1 \%$ )를 나타내었고, RCP8.5 시나리오의 $2025 \mathrm{~s}$ 에서 가장 큰 증가 (평균 
Table 4 Results of reservoir water balance

\begin{tabular}{|c|c|c|c|c|c|c|c|c|c|}
\hline \multirow{3}{*}{ Region } & \multirow{3}{*}{$\begin{array}{c}\text { Reservoir } \\
\text { name }\end{array}$} & \multirow{3}{*}{ Water flow } & \multirow{2}{*}{1990 s } & \multicolumn{3}{|c|}{ RCP4.5 } & \multicolumn{3}{|c|}{ RCP8.5 } \\
\hline & & & & $2025 \mathrm{~s}$ & $2055 \mathrm{~s}$ & $2085 \mathrm{~s}$ & $2025 \mathrm{~s}$ & $2055 \mathrm{~s}$ & $2085 \mathrm{~s}$ \\
\hline & & & $\left(10^{3} \mathrm{~m}^{3}\right)$ & \multicolumn{3}{|c|}{$\left(10^{3} \mathrm{~m}^{3}\right)$} & \multicolumn{3}{|c|}{$\left(10^{3} \mathrm{~m}^{3}\right)$} \\
\hline \multirow{9}{*}{$\begin{array}{l}\text { Central } \\
\text { region }\end{array}$} & \multirow{3}{*}{ Yooshin } & Inflow & 5,688.0 & 6,435.7 & 7,170.8 & 6,871.2 & 6,406.5 & 6,924.1 & $7,7,944.9$ \\
\hline & & Release & $1,162.5$ & $1,235.4$ & $1,169.9$ & $1,233.7$ & $1,244.5$ & $1,190.8$ & $1,194.0$ \\
\hline & & Overflow & $4,621.2$ & $5,336.4$ & $6,117.5$ & $5,752.9$ & $5,331.4$ & $5,819.3$ & $6,862.3$ \\
\hline & \multirow{3}{*}{ Nogok } & Inflow & $1,406.2$ & $1,602.1$ & $1,786.7$ & $1,708.1$ & $1,597.5$ & $1,722.6$ & $1,982.2$ \\
\hline & & Release & 299.8 & 314.6 & 298.2 & 314.2 & 318.3 & 303.6 & 304.0 \\
\hline & & Overflow & $1,150.8$ & $1,338.7$ & $1,545.5$ & $1,446.6$ & $1,330.3$ & $1,470.6$ & $1,738.5$ \\
\hline & \multirow{3}{*}{ Kumsung } & Inflow & $2,226.0$ & $2,425.6$ & $2,688.8$ & $2,579.8$ & $2,415.6$ & $2,599.3$ & $2,962.3$ \\
\hline & & Release & 805.7 & 851.5 & 806.8 & 850.2 & 859.2 & 821.4 & 822.7 \\
\hline & & Overflow & $1,651.4$ & $1,872.8$ & $2,169.9$ & $2,011.2$ & $1,870.1$ & $2,050.9$ & $2,428.3$ \\
\hline \multirow{9}{*}{$\begin{array}{l}\text { Southern } \\
\text { region }\end{array}$} & \multirow{3}{*}{ Songgok } & Inflow & $1,947.3$ & $2,501.6$ & $2,624.0$ & $2,644.6$ & $2,295.4$ & $2,745.4$ & $3,231.5$ \\
\hline & & Release & 707.2 & 675.8 & 732.3 & 721.7 & 716.0 & 717.5 & 718.2 \\
\hline & & Overflow & $1,403.5$ & $1,989.0$ & $2,114.3$ & $2,123.8$ & $1,773.8$ & $2,192.0$ & $2,706.6$ \\
\hline & \multirow{3}{*}{ Gapyung } & Inflow & $1,560.6$ & $2,004.6$ & $2,113.5$ & $2,129.0$ & $1,839.0$ & $2,212.1$ & $2,607.5$ \\
\hline & & Release & 435.8 & 416.3 & 451.0 & 444.4 & 441.0 & 441.8 & 442.3 \\
\hline & & Overflow & $1,158.5$ & $1,633.8$ & $1,728.2$ & $1,739.0$ & $1,444.9$ & $1,818.0$ & $2,222.2$ \\
\hline & \multirow{3}{*}{ Seoma } & Inflow & $2,120.2$ & $2,717.7$ & $2,870.2$ & $2,891.4$ & $2,492.7$ & $2,999.2$ & $3,531.3$ \\
\hline & & Release & 525.0 & 503.2 & 530.5 & 524.0 & 530.5 & 520.9 & 516.2 \\
\hline & & Overflow & $1,662.2$ & $2,307.0$ & $2,436.3$ & $2,462.4$ & $2,042.1$ & $2,576.2$ & $3,131.8$ \\
\hline
\end{tabular}

$6.6 \%)$ 를 보였다. 남부지방 저수지의 경우는 RCP4.5 시나리오 의 $2025 \mathrm{~s}$ 에서 감소 (평균 $-4.4 \%$ )를 나타내었으며, $2055 \mathrm{~s}$ 에 서 가장 큰 증가 (평균 $2.7 \%$ )를 보였다.

저수지의 월류량의 경우 기준기간 대비 가장 작게 증가한 경 우는 중부지방의 금성저수지로 RCP8.5 시나리오의 $2025 \mathrm{~s}$ 에서 $13.2 \%$ 증가를 나타내었고, 가장 크게 증가한 경우는 남부지방 의 2 5년 빈도 저수지인 송곡 저수지로 $92.8 \%$ 증가를 보였 다. 또한, 6 개 대상저수지에 대하여 RCP8.5 시나리오의 $2025 \mathrm{~s}$ 에서 가장 작은 증가를 나타내었고 RCP8.5 시나리오의 2085s 에서 가장 큰 증가를 나타내었는데, 이는 저수지의 유입량과 같 은 경향을 보여주고 있으며 유입량은 월류량에 큰 영향을 미치 기 때문으로 판단된다.

\section{4. 농업용저수지의 용수공급능력 평가}

각 저수지의 시나리오에 따른 시기별 (2025s, 2055s, 2085s) 연최대 필요저수량을 산정하기 위해 시계열을 작성하고, 확률분 포형의 매개변수를 추정한 후 적합도 검정을 통하여 $\mathrm{GEV}$ 분포 형을 최적확률분포형으로 선정하였다. 유효저수용량과의 비교를 통하여 재현기간 변화를 분석하였고, 결과는 Table 5 와 같다.

중부지방의 저수지는 RCP4.5 시나리오의 미래시기와 RCP8.5 시나리오의 $2025 \mathrm{~s}$ 에서 남부지방의 저수지는 RCP4.5 시나리오
Table 5 Drought return period by annual maximum water requirement

\begin{tabular}{c|c|c|r|r|r|r|r|r}
\hline \multirow{2}{*}{ Region } & \multirow{2}{*}{$\begin{array}{c}\text { Reservoir } \\
\text { name }\end{array}$} & \multirow{2}{*}{\begin{tabular}{c} 
1990s \\
\cline { 3 - 9 }
\end{tabular}} & & \multicolumn{3}{|c|}{ RCP4.5 } & \multicolumn{3}{c}{ RCP8.5 } \\
\cline { 3 - 9 } & & (year) & \multicolumn{3}{|c|}{ (year) } & \multicolumn{3}{c}{ (year) } \\
\hline \hline \multirow{2}{*}{$\begin{array}{c}\text { Central } \\
\text { region }\end{array}$} & Yooshin & 3.3 & 2.2 & 3.0 & 2.9 & 2.1 & 4.1 & 5.0 \\
\cline { 2 - 9 } & Nogok & 8.6 & 4.8 & 8.0 & 9.3 & 3.5 & 30.8 & 15.6 \\
\cline { 2 - 9 } & Kumsung & 11.1 & 4.7 & 9.0 & 6.1 & 3.3 & 18.6 & 13.8 \\
\hline \multirow{2}{*}{$\begin{array}{c}\text { Southern } \\
\text { region }\end{array}$} & Songgok & 2.6 & 3.7 & 2.1 & 2.5 & 2.8 & 3.9 & 3.6 \\
\cline { 2 - 9 } & Gapyung & 7.1 & 26.5 & 4.4 & 6.7 & 8.6 & 34.8 & 48.0 \\
\cline { 2 - 9 } & Seoma & 18.2 & 333.3 & 10.5 & 16.4 & 19.6 & 250 & 500 \\
\hline
\end{tabular}

의 $2055 \mathrm{~s}, 2085 \mathrm{~s}$ 에서 기준기간의 저수지 설계빈도와 비교하였 을 때 재현기간이 감소하는 것으로 분석되었다. 특히 중부지방 의 10 년 빈도 이상 저수지인 금성 저수지는 RCP8.5 시나리오의 $2025 \mathrm{~s}$ 에서 $70 \%$ 감소율을 보여 가장 크게 감소하는 것으로 나 타났다. 이는 기후변화로 인하여 연최대 필요저수량이 저수지의 유효저수량보다 많아지기 때문에 용수공급의 실패가 커질 가능 성을 나타내며, 금성저수지의 경우 저수지에서 관개 지구에 물을 공급해야 하는 시기인 6 월에 강수일수가 평균 9.1일 (기준기간) 에서 8일 $(2025 \mathrm{~s})$ 로 감소하여 나타난 결과로 판단된다.

이외의 시기 경우는 기준기간보다 저수지의 재현기간이 증가 하는 것으로 나타났으며, 특히 남부지방의 10년 빈도 이상 저수 
지인 서마 저수지의 경우 기준기간의 재현기간이 18.2 년으로 산 정되었는데 RCP8.5 시나리오의 2085s에서는 500년 빈도 저수 지로 예상되어 증가율이 가장 크게 분석되었다. 이는 기후변화로 인하여 강수량 증가가 남부지방과 RCP8.5 시나리오의 경우 크 게 나타남에 따라 저수지의 유입량이 기준기간보다 $67 \%$ 증가 하여 충분한 용수공급이 이루어졌을 뿐만 아니라, 저수지의 방류 량이 기준기간보다 $1.7 \%$ 감소하는 것으로 나타났기 때문으로 판단된다.

연최대 필요저수량의 빈도분석을 통하여 기후변화에 따른 용 수공급의 변화는 저수지의 설계빈도 차이 보다 강수량의 증감으 로 인한 유입량의 변화에 영향을 많이 받는 것으로 분석되었고, 특히 10 년 빈도 이상의 저수지의 경우 그 증감의 차이가 다른 빈도의 저수지보다 클 것으로 예상된다.

\section{5. 농업용저수지의 가뭄대응능력 평가}

Runs 이론을 이용한 저수지의 가뭄대응능력 평가를 하기 위하 여 기준수위를 기준기간의 일별 저수량 하위 $10 \%$ 로 가정하고, 기본수준 이하일 경우에 한해 가뭄으로 처리하여 각 사상별로 기간 $(D)$, 크기 $(M)$, 강도 $(S)$ 를 산정하였다. 그러나, 어느 한 시점에서의 저수량이 기준수위보다 낮아 부족량을 나타내었으나, 강우 또는 필요수량 변화에 의하여 짧은 기간 동안에 저수량이 회복되는 경우가 발생한다. 이 경우를 가뭄이라 평가하기에는 어 렵다고 사료되어, 각 저수지의 부족량인 강도에 대해서 초과치계 열로 30 개의 자료를 이용하여 빈도분석을 실시하였다. 빈도분석 결과를 바탕으로 재현기간의 따른 강도 값을 계산한 결과는 Table 6 과 같다. 6 개 대상저수지를 대상으로 평균 강도 값은 2 년 빈도 의 경우 $186.9\left(10^{3} \mathrm{~m}^{3} \times \mathrm{day}\right), 5$ 년 빈도의 경우 $471.3\left(10^{3} \mathrm{~m}^{3}\right.$ $\times$ day), 10 년 빈도의 경우 $723.5\left(10^{3} \mathrm{~m}^{3} \times\right.$ day $), 20$ 년 빈도의 경우 $1,001.3\left(10^{3} \mathrm{~m}^{3} \times \mathrm{day}\right)$ 으로 산정되었다. 특히, 중부지방의 $5 \sim 10$ 년 빈도 저수지인 노곡 저수지는 2 년 빈도의 평균 강도가 $90.02\left(10^{3} \mathrm{~m}^{3} \times \mathrm{day}\right)$ 으로 다른 저수지에 비해 가장 작게 산출되 었지만, 2 년 빈도를 기준으로 20 년 빈도에 대한 증가율은 가장 크게 나타났다. 이는 노곡 저수지의 유효저수용량이 다른 저수지 에 비하여 작아 2 년 빈도의 강도가 가장 작게 나타났지만, 기후 변화로 인하여 20년 빈도의 강도인 극한 가뭄이 도래하였을 경 우 현재의 가뭄대응능력으로는 대처하지 못할 가능성이 높을 것 으로 예상된다.

Table 7은 5 10년 빈도의 강도를 가지는 가뭄 사상을 기준 으로 가뭄 특성치 중 지속기간과 빈도의 변화를 나타낸 것이다. 지속기간은 저수량이 기본수준 아래에 있을 경우의 최대 기간으 로 산정하였으며, 빈도는 그 횟수를 의미한다. 기준기간의 가뭄 지속기간과 비교하였을 때 증가한 경우는, 중부지방의 2 5년
Table 6 Severity with respect to the return periods

\begin{tabular}{c|r|r|r|r}
\hline \multirow{2}{*}{$\begin{array}{c}\text { Reservoir } \\
\text { name }\end{array}$} & 2-year & 5-year & 10-year & 20-year \\
\cline { 2 - 5 }$\left(10^{3} \mathrm{~m}^{3} \times\right.$ day $)$ \\
\hline \hline Yooshin & 182.14 & 548.86 & 908.61 & 1325 \\
\hline Nogok & 90.02 & 306.85 & 518.14 & 756.27 \\
\hline Kumsung & 258.02 & 558.95 & 814.31 & 1086.6 \\
\hline Songgok & 189.63 & 485.8 & 757.89 & 1061.2 \\
\hline Gapyung & 155.29 & 422.57 & 646.75 & 884.19 \\
\hline Seoma & 246.32 & 504.73 & 695.39 & 894.48 \\
\hline
\end{tabular}

Table 7 Duration and frequency by $5 \sim 10$ year return period

\begin{tabular}{|c|c|c|c|c|c|c|c|c|}
\hline & \multicolumn{6}{|c|}{ Reservoir name } \\
\hline & & & Yooshin & Nogok & Kumsung & Songgok & Gapyung & Seoma \\
\hline & \multirow{2}{*}{$1995 \mathrm{~s}$} & $\overline{\left(\mathrm{D}^{1)}\right.}$ & 16 & 25 & 25 & 26 & 31 & 32 \\
\hline & & $\mathrm{F}^{2)}$ & 1 & 3 & 4 & 2 & 6 & 4 \\
\hline \multirow{6}{*}{ RCP4.5 } & \multirow{2}{*}{$2025 \mathrm{~s}$} & $\mathrm{D}$ & 11 & 21 & 9 & 23 & 13 & 15 \\
\hline & & $\mathrm{F}$ & 5 & 6 & 3 & 2 & 2 & 2 \\
\hline & \multirow{2}{*}{$2055 \mathrm{~s}$} & $\mathrm{D}$ & 17 & 22 & 23 & 10 & 16 & 16 \\
\hline & & $\mathrm{F}$ & 8 & 5 & 4 & 2 & 1 & 1 \\
\hline & \multirow{2}{*}{$2085 s$} & $\mathrm{D}$ & 13 & 13 & 18 & 14 & 13 & 17 \\
\hline & & $\mathrm{F}$ & 4 & 1 & 3 & 1 & 4 & 2 \\
\hline \multirow{6}{*}{ RCP8.5 } & \multirow{2}{*}{$2025 \mathrm{~s}$} & $\mathrm{D}$ & 42 & 25 & 23 & 16 & 14 & - \\
\hline & & $\mathrm{F}$ & 1 & 5 & 5 & 3 & 1 & - \\
\hline & \multirow{2}{*}{$2055 \mathrm{~s}$} & $\mathrm{D}$ & 11 & 13 & 11 & 11 & 15 & 18 \\
\hline & & $\mathrm{F}$ & 5 & 2 & 1 & 2 & 2 & 1 \\
\hline & \multirow{2}{*}{$2085 \mathrm{~s}$} & $\mathrm{D}$ & 14 & 18 & 25 & 21 & 15 & 15 \\
\hline & & $\mathrm{F}$ & 3 & 3 & 4 & 3 & 4 & 1 \\
\hline
\end{tabular}

1) D : Duration (days)

2) $\mathrm{F}:$ Frequency (times)

빈도 저수지인 유신 저수지로서 RCP4.5 시나리오의 $2055 \mathrm{~s}$ 에서 1 일, $\mathrm{RCP} 8.5$ 시나리오의 $2025 \mathrm{~s}$ 에서는 26 일 증가하는 것으로 나타났다. 특히, RCP8.5 시나리오의 $2025 \mathrm{~s}$ 에는 지속기간은 증가 하였으나 빈도는 1 번으로 나타났는데, 이는 가뭄이 발생한 2034 년의 4월 강수량이 $5.7 \mathrm{~mm}$ 로 2025s의 4 월 평균 강수량인 107.4 $\mathrm{mm}$ 와 비교하여 적었기 때문에 저수지의 유입량 부족으로 판단 된다. 이 경우를 제외한 나머지 저수지와 미래 시기에서는 기준 기간과 비교하여 가뭄 지속기간이 감소하는 것으로 나타났는데, 특히 남부지방의 10 년 이상 빈도를 가진 서마 저수지 경우는 RCP 8.5 시나리오의 $2025 \mathrm{~s}$ 에서 가뭄 지속기간과 빈도가 나타나지 않 을 것으로 예상되었다. 이는 남부지방의 강수 증가 경향이 크기도 하지만, 관개면적이 다른 저수지보다 작기 때문으로 판단된다.

유신과 서마 저수지의 경우 RCP8.5 시나리오와 2025s에서 같 은 지방의 빈도가 다른 저수지들과 다른 경향 또는 극명한 차이 를 보임에 따라 저수지 설계빈도에 따른 미래의 가뭄대응능력이 검토되어야 할 것으로 사료된다. 


\section{IV. 요약 및 결론}

본 연구에서는 기후변화에 따른 지역별 및 저수지의 설계빈 도를 고려한 저수지의 용수공급능력과 가뭄대응능력을 평가하기 위해 CCCma에서 제공하고 있는 CanESM2의 RCP4.5 및 8.5 시나리오를 활용하여 연최대 필요저수량의 빈도분석과 Runs 이 론을 적용하였다. 그 결과를 요약하면 다음과 같다.

1. 유출량 및 논벼 작물증발산량 산정 결과는 다음과 같다. 유 출량의 경우 RCP4.5 및 8.5 시나리오에서 중부 및 남부지방의 모든 저수지는 기준기간과 비교하였을 때 증가하는 경향을 보 였고, 증가율은 남부지방이 중부지방보다 약 $15.4 \%$ 큰 것으로 나타났다. 작물증발산량 또한 미래시기에 증가하는 경향을 나타 내었으며 평균 증가 비율은 $7.5 \%$ (2025s), $22.9 \%$ (2055s), $33.0 \%$ (2085s)이었다.

2. 저수지의 용수공급능력을 연최대 필요저수량의 빈도분석 을 통한 재현기간의 변화로 평가하고자 하였다. 기준기간의 저 수지 설계빈도와 비교하였을 때 중부지방의 저수지는 RCP4.5 시나리오의 미래시기 $(-24.4 \%)$ 와 RCP8.5 시나리오의 $2025 \mathrm{~s}$ (-55.3\%)에서, 남부지방의 저수지는 RCP4.5 시나리오의 $2055 \mathrm{~s}$ $(-33.2 \%)$, 2085s $(-6.5 \%)$ 에서 재현기간이 감소하는 것으 로 분석되었다. 반면에, 남부지방의 10 년 빈도 이상 저수지인 서 마 저수지의 경우 RCP8.5 시나리오의 2085s에서 500년 빈도 저수지로 예상되어 증가율이 가장 크게 분석되었는데, 저수지의 유입량이 기준기간보다 $67 \%$ 증가하였고, 방류량이 $1.7 \%$ 감소 하는 것으로 나타났기 때문으로 판단된다.

3. 저수지의 가뭄대응능력을 평가하기 위해, Runs 이론을 적 용하여 기준기간의 저수량 하위 $10 \%$ 저수량을 기준수위으로 정 의하였고 가뭄강도, 가뭄크기, 가뭄기간을 산정하였다. 이 중 짧 은 기간 내에 가뭄강도가 회복되는 경우를 제외하기 위하여, 가 뭄강도 값의 초과치 계열을 이용하여 빈도분석을 실시한 결과 2 년 빈도의 경우 평균 $186.9\left(10^{3} \mathrm{~m}^{3} \times \mathrm{day}\right), 5$ 년 빈도의 경우 평 균 $471.3\left(10^{3} \mathrm{~m}^{3} \times \mathrm{day}\right), 10$ 년 빈도의 경우 $723.5\left(10^{3} \mathrm{~m}^{3} \times\right.$ day), 20년 빈도의 경우 $1,001.3\left(10^{3} \mathrm{~m}^{3} \times \mathrm{day}\right)$ 으로 나타났다. 이 중 5 10년 빈도를 가지는 가뭄강도를 바탕으로 지속기간과 빈도를 산정한 결과, 중부지방의 2 5년 빈도 저수지인 유신 저 수지의 경우 RCP8.5 시나리오의 $2025 \mathrm{~s}$ 에서 지속기간이 42 일로 기준기간에 비해 증가하였다. 상대적으로 같은 시나리오와 시기 에 대하여 남부지방의 10 년 빈도 이상 저수지인 서마 저수지의 경우는 지속기간과 빈도가 나타나지 않았으며, 이는 연강수량이 증가하여 저수지의 유입량 증가에 영향을 주기 때문으로 판단된 다. 그러나 강수량 편차 또한 증가하기 때문에 현재보다 가뭄에 대응하는 능력이 감소하는 시기가 발생하며 그 피해는 저수지 설계빈도가 작은 저수지 (2 5년 빈도)에서 클 것이라 예상된다.
기후변화에 따른 기온 상승과 강수량 증가로 인하여 저수지의 방류량과 유입량 증가가 예상되며, 이러한 변화는 농업용 저수지 의 안정적인 용수공급에 있어 영향을 미칠 수 있다. 따라서 지역 차이 및 설계빈도 차이를 고려한 뿐만 아니라 유역면적 및 관개 면적 등 다양한 저수지의 설정을 통한 추가 연구가 필요할 것으 로 판단된다. 본 연구 결과는 향후 기후변화로 인한 농업용수 변 화를 파악하고 전망함으로써 저수지의 효율적인 공급 계획 수립 의 기초자료로서 활용될 수 있을 것으로 판단된다.

\section{REFERENCES}

1. Ahn, S. R., G. A. Park, Y. H. Shin, and S. J. Kim, 2009. Assessment of the potential water supply rate of agricultural irrigation facilities using MODSIM for geum river basin -. Journal of the Korean Society of Civil Engineers 42(10): 825-843 (in Korean).

2. Ahn, S. S., S. D. Jeong, J. S. Lee, K. D. Yoon, and I. S. Chang, 2002. A study on the determination of water storage-supply capacity of agricultural reservoir. Journal of the Environmental Sciences 11(12): 1217-1226 (in Korean).

3. Choi, D., J. H. Ahn, D. J. Jo, and S. Kim, 2010. Estimating climate change impact on drought occurrence based on the soil moisture PDF. Journal of Korea Water Resources Association 43(8): 709-720 (in Korean).

4. Chung, S. O., 2012. Projection of paddy rice consumptive use in the major plains of the Korean peninsula under the RCP scenarios. Journal of the Korean Society of Agricultural Engineers 54(5): 35-41 (in Korean).

5. Chylek, P., J. Li, M. K. Dubey, M. Wang, and G. Lesins, 2011. Observed and model simulated 20th century arctic temperature variability: Canadian Earth System Model CanESM2. Atmospheric Chemistry and Physics Discussions 11: 22893-22907.

6. Ho, C. K., D. B. Stephenson, M. Collins, C. A. T. Ferro, and S. J. Brown, 2012. A source of additional uncertainty in climate change projections. Bulletin of the American Meteorological Society 93(1): 21-26.

7. Hong, E. M., J. Y. Choi, S. H. Lee, S. H. Yoo, and M. S. Kang, 2009. Estimation of paddy rice evapotranspiration considering climate change using LARS-WG. Journal of the Korean Society of Agricultural Engineers 51(3): 25-35 (in Korean). 
8. Jang, M. W., H. W. Chung, J. Y. Choi, K. W. Park, and S. J. Bae, 2004. Development of a single reservoir agricultural drought evaluation model for paddy. Journal of the Korean Society of Agricultural Engineers 46(3): $17-30$.

9. Kang, H. S., H. J. Baek, K. O. Boo, and C. H. Jo, 2012. New climate change scenarios based on Representative Concentration Pathways. Magazine of Korea Water Resource Association 45(3): 73-79 (in Korean).

10. Kim, H. Y. and S. W. Park, 1988. Simulating daily inflow and release rates for irrigation reservoir (II) - Modeling reservoir release rates -, Journal of the Korean Society of Agricultural Engineers 30(2): 95104 (in Korean).

11. Kim, S. J., K. Y. Lee and S. J. Kang, 1998. Statistical Analysis of Irrigation Reservoir Water Supply Index. Journal of the Korean Society of Agricultural Engineers 40(4): 58-66 (in Korean).

12. Korea Meteorological Administration (KMA), 2011. How does it utilize, regional climate change information? focusing on establish adaptation policies of climate change - (in Korean).

13. Korea Meteorological Administration (KMA), 2012. Web system tutorials for climate change scenarios (in Korean).

14. Lee, D. R., J. W. Moon, D. H. Lee and J. H. Ahn, 2006. Development of water supply capacity index to monitor droughts in a reservoir. Journal of the Korean Water Resources Association 39(3): 199-241 (in Korean).

15. Lee, K. Y., 2000. Development of estimation system for agricultural water demand. Ph.D. thesis, Konkuk University, Seoul, Republic of Korea (in Korean).

16. Lee, T., J. Y. Choi, S. H. Yoo, S. H. Lee, and Y. G. Oh, 2012. Analyzing consumptive use of water and yields of paddy rice by climate change. Journal of the Korean Society of Agricultural Engineers 54(1): 47-54 (in Korean).

17. Lim, H. J., H. J. Kwon, D. H. Bae, and S. J. Kim, 2006. Analysis of hydrological impact using climate change scenarios and the CA-Markov technique on Soyanggang-dam watershed. Journal of Korea Water Resources Association 39(5): 453-466 (in Korean).
18. Ministry of Agriculture and Forestry (MAF). 2002. Design criteria of land and water development plan for agriculture (fill dam). (in Korean).

19. Nam, W. H., J. Y. Choi, T. Kim, and J. J. Lee, 2012. Vulnerability assessment of water supply in agricultural reservoir utilizing probability distribution and reliability analysis methods. Journal of the Korean Society of Agricultural Engineers 54(2): 37-46 (in Korean).

20. National Institute of Meteorological Research (NIMR), 2011. Climate Change Scenario report for the IPCC $5^{\text {th }}$ assessment report. Seoul, Korea. 117pp. (in Korean).

21. Park, G. A., H. J. Shin, M. S. Lee, W. Y. Hong, and S. J. Kim, 2009. Future potential impacts of climate change on agricultural watershed hydrology and the adaptation strategy of paddy rice irrigation reservoir by release control. Journal of the International Society of Paddy and Water Environment Engineering 7(4): 271-282.

22. Park, G. A., S. R. Ahn, M. J. Park, and S. J. Kim, 2010. Assessment of the contribution of weather, vegetation and land use change for agricultural reservoir and stream watershed using the SLURP model (II ) calibration, validation and application of the model -. Journal of the Korean Society of Civil Engineers 30(2B): 121-135 (in Korean).

23. Park, M. K., J. H. Kim and K. S. Jung, 2002. A study of optinal operation policy using risk evaluation criteria ( I ). Journal of the Korean Water Resources Association 35(1): 37-49 (in Korean).

24. Park, M., Y. N. Yoon and D. R. Lee, 1999. An application of drought frequency formula for the determination of reservoir capacity and the evaluation of water supply capability. Proceedings of the Korea Water Resources Association Conference 56-61 (in Korean).

25. Rural Infrastructure Management System (RIMS), http://rims.ekr.or.kr. Accessed 1 Jan. 2013.

26. So, B. J., M. J. Kim, and H. H. Kwon, 2012. Projection and assessment of climate change scenarios provided by Korea Meteorological Administration. Magazine of Korea Water Resource Association 45(8): 56-70 (in Korean). 
27. Xu, Y., and C. H. Xu, 2012. Preliminary assessment of simulations of climate change over China by CMIP5 multi-models. Atmospheric and Oceanic Science Letters 5(6): 489-494.

28. Yoo, S. H., J. Y. Choi, S. H. Lee, Y. G. Oh, and N. Y. Park, 2012a. The impacts of climate change on paddy water demand and unit duty of water using highresolution climate scenarios. Journal of the Korean Society of Agricultural Engineers 54(2): 15-26 (in Korean).
29. Yoo, S. H., J. Y. Choi, W. H. Nam, and E. Hong, 2012b. Analysis of design water requirement of paddy rice using frequency analysis affected by climate change in South Korea, Agricultural Water Management 112: $33-42$.

30. Yun, D. K., S. O. Chung and S. J. Kim, 2011. Climate change impacts on paddy water requirement. Journal of the Korean Society of Agricultural Engineers 53(4): 39-47 (in Korean). 